\title{
Response of Brinjal (Solanum melongena L.) cultivars to Nitrogen levels
}

\author{
Bibi Zainub, Gohar Ayub, Sajid Siddique*, Shah Zeb and Ehtesham \\ Jamil \\ Department of Horticulture, TheUniversity of Agriculture, Peshawar, Pakistan \\ *Corresponding author's email: sajidsiddique39@gmail.com \\ Citation \\ Bibi Zainub, Gohar Ayub, Sajid Siddique, Shah Zeb and Ehtesham Jamil. Response of Brinjal (Solanum melongena \\ L.) cultivars to Nitrogen levels. Pure and Applied Biology. Vol. 5, Issue 1, 2016, pp134-141. \\ http://dx.doi.org/10.19045/bspab.2016.50018
}

Received: 05/10/2015 Revised: 11/01/2016 Accepted: 18/01/2016

Online First: 01/02/2016

\section{Abstract}

Nitrogen is an essential nutrient for both vegetative and reproductive growth of plants. Above and below the optimum level vegetative as well as the reproductive growth negatively affected therefore the experiment was designed to evaluate the response of brinjal cultivars to various levels $\left(0,70,100\right.$, and $\left.130 \mathrm{~kg} \mathrm{ha}^{-1}\right)$ of nitrogen in the year of 2014. All the treatments were randomly assigned with split plot arrangement with three replicates. Nitrogen levels were considered as main plot treatments and brinjal cultivars (Shamli, Black Long, Purple Long) as subplot treatments. Both cultivars and nitrogen levels showed significant difference among growth parameters. Plant height, days to flowering, days to fruiting, number of leaves plant ${ }^{-1}$, number of fruits plant ${ }^{-1}$, fruit weight, total yield and survival percentage were significantly increased by nitrogen levels. Maximum plant height $(138.22 \mathrm{~cm})$, number of leaves plant ${ }^{-}$ ${ }^{1}$ (434.44), days to fruiting (64), days to flowering (39), fruit weight $(74.50 \mathrm{~g})$, number of fruits plant ${ }^{-1}(16.37)$, total yield $\left(13.72 \mathrm{t} \mathrm{ha}^{-1}\right)$ and survival percentage (98.50\%) were observed in plots received nitrogen at $130 \mathrm{~kg} \mathrm{ha}^{-1}$, however, control plots were recorded with the lowest survival percentage. Among cultivars, maximum plant height $(120.83 \mathrm{~cm})$, days to flowering (38), days to fruiting (54), number of leaves plant ${ }^{-1}$ (349.17), fruit weight (72.42g), total fruits plant ${ }^{-1}$ (15.37), total yield $\left(13.26 \mathrm{t} \mathrm{ha}^{-1}\right)$ and survival percentage (95.38\%), were recorded in cultivar Purple Long, while minimum values for these parameters were recorded in cultivar Black long. It is concluded from the results that cultivar Purple Long with $130 \mathrm{~kg} \mathrm{~N}^{-1}$ showed better results regarding growth and yield; hence it is recommended to cultivate mentioned cultivar under the agro climatic condition of Peshawar for optimum growth and yield.

Key words: Solanum melongena L.; Nitrogen dose; Brinjal cultivars; Growth; Production

\section{Introduction}

Selection of variety is important consideration regarding bringal cultivation as its performance depends on climate of region. In another area fruit may be totally rejected with a particular variety having specific color and size fetching premium prize in the market. Farmers get maximum return of his produce, judicious selection of the type with reference to market demand is very important in this crop. Some of cultivars of eggplant (purple long, black long and shamli) will be studied in this research. Purple long eggplant is annual and 
it is an Italian variety. Bringal plant consists of many branches and fruit is dark-purple color with a length of 8-10 inches long. It is well grown in northern climates. Black long eggplant is the common variety in U.S. Most familiar varieties are bell black, black magic and black beauty having large elongate oval shape with smooth skin and deep purple color [1].

For plant growth nitrogen is the main chemical element which is required for good vegetative growth. Nitrogen imports dark green color to leaves. Nitrogen is combined with chlorophyll utilized sun light and carryout essential plant functions. Nitrogen absorbed by plants in the form of nitrates and ammonium ions. In plants, nitrogen also produces proteins and nucleic acid and it is readily transported from older tissues to younger tissues. Yellowing and chlorosis in leaves is due to nitrogen deficiency. Older leaves start yellowing and continue to the younger leaves. Due to nitrogen deficiency plants show stunted growth, poor production and low yield [2]. The application of nitrogen increase plant height, fruit size and fruit yield. Yield response of brinjal to nitrogen fertilization varied with plant spacing [3].

Brinjal (Solanum melongena L.) popularly known as eggplant belongs to the family Solanaceous. Eggplant cultivars are characterized as tall plant with large spiny leaves, calyx and stems, bearing inflorescences with andromonoecy and producing small green bitter fruits with thick skin, hard flesh and many seeds [4].

The fruit is fleshy berry and color changes from shiny purple to white, green, yellow and black. Fruit shape varies from long cylindrical to round, oblong and oval shape [5]. Fruit length may vary from 4 to $45 \mathrm{~cm}$ and diameter between 3 to $35 \mathrm{~cm}$ and weight approximately $0.5 \mathrm{~g}$ to $1500 \mathrm{~g}$ [4]. Brinjal is normally a self-pollinated crop although cross pollination does occur [6].
Brinjal is best grown in both tropical and sub-tropical areas. It is popular in India and it is derived from Arabic and Sunskrit. Brinjal fruits may vary in shapes and varieties, some varieties are white in color and resemble to chicken eggs. Brinjal are grown in Pakistan, India, Bangladesh, China, Japan, Syria and Western Europe [7]. Brinjal is a good source of nutrients, vitamins, minerals, antioxidant, dietary fiber and proteins [8]. It also contain good amount of protein, iron and carbohydrates (1.3\%, $0.0013 \%$ and $6.4 \%$ ). Brinjal fruit contains bcarotene, ascorbic acid and riboflavin (34mg, $0.9 \mathrm{mg}, 0.05 \mathrm{mg}$ ) per $100 \mathrm{~g}$. Brinjal is used in a variety of culinary preparation since ancient times. It is staple vegetable in tropical countries. Purple fruits have higher amino acid content.

Nutrients in plants are very important for improving yield and quality in brinjal. Production of eggplant can be on effective agriculture soil using proper management practices. Good fertile, well drained and sandy loam soil having $\mathrm{pH}$ of 5.5-6.8 are necessary for better growth and development [9].

Based on the importance of nitrogen for brinjal cultivars, the current research is therefore conducted to evaluate the suitable level of nitrogen for optimal vegetative and reproductive growth of brinjal and to select the best brinjal cultivar for Peshawar growers.

\section{Materials and Methods}

An experiment entitled "Response of brinjal (Solanum melongena L.) cultivars to nitrogen levels" were conducted at Horticulture Research Farm, The University of Agriculture Peshawar, during the year 2014.Brinjal seeds were sown in pots. When seedling attained equal height, they were transplanted in to the field. Ridges were prepared manually at appropriate height. Plants and rows were spaced $30 \mathrm{~cm}$ and $60 \mathrm{~cm}$ respectively. Bed sizes were kept as 
$3 \mathrm{~m}^{2}$.Three cultivars of brinjal and four levels of nitrogen were used. Irrigation was done when required. Regular culture practices were done throughout the experiment. Before transplantation Basal dose of Phosphorus (50 kg ha-1) and Potassium $\left(50 \mathrm{~kg} \mathrm{ha}^{-1}\right)$ were applied to the field. Half dose of nitrogen was applied before transplantation, while remaining half after 20 days of transplantation. Urea (46\%

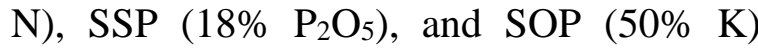
were used as source of $\mathrm{N}, \mathrm{P}$ and $\mathrm{K}$ respectively. The present research was laid out in Randomize Complete Block (RCBD) with split plot arrangement. The experiment was having two factors, factor $\mathrm{A}$ was nitrogen doses $\left(0,70,100 \& 130 \mathrm{~kg} \mathrm{ha}^{-1}\right)$ and factor B was cultivars (Shamli, Black long \& Purple) long and were replicated three times.

\section{Soil Analysis}

$25 \mathrm{~cm}$ depth of soil sample were taken from randomly selected five different parts of the field, before the fertilizer application and their chemical properties were analyzed in soil lab. Analysis (chemical) of experimental soil at $25 \mathrm{~cm}$ depth having Nitrogen (0.042\%), Phosphorus (9.00mg $\mathrm{kg}^{-1}$ ), Potassium (110mg kg-1), Organic matter (0.83\%), $\mathrm{pH}$ (7.3) and Texture class (Clay loam).

\section{Parameters}

Data was recorded for various vegetative and reproductive components of brinjal plant during the experimental trial. Randomly plants were selected to record data for plant height. For this purpose five plants were tagged and measured their heights from its bottom to the top of plant. Plants were randomly tagged for counting average number of leaves for each plant in all experimental units. After transplantation of seedlings to the first appearance of flower and fruit sitting were considered as days to flowering and number of days to fruiting. For this purpose tagged plants were observed thoroughly and days were recorded and then their means were computed. Numbers of fruits were counted from randomly selected five plants in each treatment and their means were calculated. At each harvest individual fruit of randomly selected plants was calculated and then their averages were calculated. The yield (tons $\mathrm{ha}^{-1}$ ) and survival percentage (\%) was calculated with formula.

Survival percentage $(\%)=$ Total number of plants survived x 100

Number of total plants sprouted

\section{Statistical procedure}

Data was analyzed statistically using computer software statistix-8.0 to know the significant difference among various parameters. LSD was applied at $5 \%$ level of probability.

\section{Results and discussion}

The results and discussion of the recorded data regarding response of Brinjal cultivars to nitrogen levels are briefly explained.

\section{Plant height (cm)}

Significant variation was observed for plant height among Brinjal cultivars and nitrogen levels, however, both were found without any significant interaction. Means values for nitrogen levels showed that the tallest plant $(138.22 \mathrm{~cm})$ were recorded in plants supplied with $130 \mathrm{~kg} \mathrm{~N} \mathrm{ha}^{-1}$, followed by $(124.44 \mathrm{~cm})$ at $100 \mathrm{~kg} \mathrm{ha}^{-1}$ and $(107.44 \mathrm{~cm})$ at $70 \mathrm{~kg} \mathrm{ha}^{-1}$ respectively, while lowest plant height $(102.78 \mathrm{~cm})$ was recorded in control treatment. Means values of plant height for cultivars showed that the tallest plant $(120.83 \mathrm{~cm})$ were recorded in cultivar Purple Long, followed by $(117.00 \mathrm{~cm})$ in Shamli cultivar, while lowest plant height $(116.83 \mathrm{~cm})$ was recorded in Black Long (Table 1). 
Table 1. Response of Brinjal (solanum melongena L.) cultivars to Nitrogen levels

\begin{tabular}{|c|c|c|c|c|c|c|c|c|}
\hline $\begin{array}{l}\text { Nitrogen } \\
\text { level (kg } \\
\left.\text { ha }^{-1}\right)(\mathbf{N})\end{array}$ & $\begin{array}{c}\text { Plant } \\
\text { height } \\
(\mathbf{c m})\end{array}$ & $\begin{array}{l}\text { No. of } \\
\text { leaves } \\
\text { plant }^{-1}\end{array}$ & $\begin{array}{c}\text { No. of } \\
\text { days to } \\
\text { flowering }\end{array}$ & $\begin{array}{c}\text { No. of } \\
\text { days to } \\
\text { fruiting }\end{array}$ & $\begin{array}{l}\text { No. of } \\
\text { fruits } \\
\text { plant }^{-1}\end{array}$ & $\begin{array}{c}\text { Fruit } \\
\text { weight } \\
\text { (g) }\end{array}$ & $\begin{array}{c}\text { Total } \\
\text { yield } \\
(\mathrm{t} \mathrm{ha-1)}\end{array}$ & $\begin{array}{c}\text { Survival } \\
\text { percenta } \\
\text { ge }(\%)\end{array}$ \\
\hline 0 & $102.78 d$ & $225.0 d$ & $30.57 \mathrm{c}$ & $40.66 \mathrm{~d}$ & $9.03 c$ & $62.27 \mathrm{c}$ & $8.75 c$ & $73.80 \mathrm{c}$ \\
\hline 70 & $107.44 \mathrm{c}$ & $343.56 c$ & $34.50 \mathrm{~b}$ & $50.44 \mathrm{c}$ & $11.88 \mathrm{~b}$ & $66.80 \mathrm{bc}$ & $10.55 \mathrm{bc}$ & $86.11 \mathrm{~b}$ \\
\hline 100 & $124.44 b$ & $382.78 b$ & $36.80 \mathrm{ab}$ & $53.00 \mathrm{~b}$ & $12.85 \mathrm{~b}$ & $70.30 \mathrm{ab}$ & $11.90 \mathrm{ab}$ & $94.20 \mathrm{a}$ \\
\hline 130 & $138.22 \mathrm{a}$ & $444.4 \mathrm{a}$ & $39.40 \mathrm{a}$ & $64.55 a$ & $16.37 \mathrm{a}$ & $74.50 \mathrm{a}$ & $13.72 \mathrm{a}$ & $98.50 \mathrm{a}$ \\
\hline LSD & 1.84 & 5.24 & 0.889 & 2.02 & 1.4 & 6.58 & 2.74 & 5.10 \\
\hline \multicolumn{9}{|c|}{ Cultivars (C) } \\
\hline Shamli & $117.00 \mathrm{~b}$ & $345.33 b$ & $35.10 \mathrm{~b}$ & $52.83 \mathrm{ab}$ & $12.75 \mathrm{~b}$ & $67.65 \mathrm{a}$ & $11.80 \mathrm{~b}$ & $88.11 \mathrm{~b}$ \\
\hline $\begin{array}{c}\text { Black } \\
\text { Long }\end{array}$ & $116.83 b$ & $344.83 b$ & $32.60 \mathrm{c}$ & $50.00 \mathrm{~b}$ & $9.47 \mathrm{c}$ & $63.32 b$ & $8.64 c$ & $81.15 \mathrm{c}$ \\
\hline $\begin{array}{l}\text { Purple } \\
\text { Long }\end{array}$ & $120.83 a$ & $349.473 a$ & $38.25 \mathrm{a}$ & $53.91 \mathrm{a}$ & $15.37 \mathrm{a}$ & $72.42 \mathrm{a}$ & $13.26 \mathrm{a}$ & $95.38 \mathrm{a}$ \\
\hline LSD & 2.66 & 2.76 & 2.01 & 2.75 & 1.0 & 3.53 & 1.13 & 3.72 \\
\hline $\mathbf{N} \times \mathbf{C}$ & $\mathrm{NS}$ & $\mathrm{NS}$ & NS & $\mathrm{NS}$ & NS & $\mathrm{NS}$ & $\mathrm{NS}$ & $\mathrm{NS}$ \\
\hline
\end{tabular}

The results showed that high levels of nitrogen increased plant height in eggplant. The same results were obtained by Wange and Kale [10], who reported that, plant height was significantly improved by nitrogen. Similar results were found by Pervez et al. [11], who reported that soil nutrients are very important for plant height, hence nitrogen application increased the plant height and increased yield ultimately. While increasing dose of nitrogen, positive response on the plant height was observed earlier by other researchers [12]. Nitrogen application at the rate of $130 \mathrm{~kg}$ resulted in improved vegetative growth [13].

\section{Number of leaves plant ${ }^{-1}$}

The statistical analysis of the data shows significant differences for number of leaves plant $^{-1}$ regarding different cultivars and nitrogen levels, while their association was found non-significant. Means values for nitrogen levels showed that more number of leaves plant ${ }^{-1}$ (434.44) was recorded in

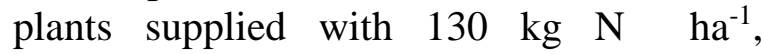

followed by (382.78) at $100 \mathrm{~kg} \mathrm{ha}^{-1}$ and (343.56) at $70 \mathrm{~kg} \mathrm{ha}^{-1}$ respectively, while fewer number of leaves plant ${ }^{-1}$ (225.00) was recorded in control treatment. Mean values of number of leaves plant ${ }^{-1}$ for cultivars showed that maximum number of leaves plant $^{-1}$ (349.17) was recorded in cultivar Purple Long, followed by (345.33) in Shamli cultivar, while minimum (344.83) was recorded in cultivar Black Long (Table $1)$.

Nitrogen plays an important role in chlorophyll and protein synthesis. Vegetative growth improved ultimately when best possible nutrition combined with adequate amount of Nitrogen available to the plants. There is correlation between leaves and branches, hence high number of branches results in increase number of leaves. These results are in line with some earlier studies, who stated increased number of leaves as a result of high dose of nitrogen application [2]. Akanbi et al. [14] also reported that nitrogen increased the number 
of leaves plant ${ }^{-1}$.Increase levels of inorganic fertilizers results in more number of leaves plant $^{-1}$, as compared to those plots which were unfertilized (control). It may be the cause of available nitrogen, which improved the soil water holding capacity [15]. The current findings are similar to some prior studies, which prove that increased level of nitrogen results in better vegetative growth and high yield ultimately [13].

\section{Days to flowering}

The statistical analysis of the data showed that days to flowering were significantly affected for different cultivars and nitrogen levels, while their interaction was found non-significant. Means value days to flowering for nitrogen levels showed that maximum days to flowering (39.40) was recorded in plants supplied with $130 \mathrm{~kg} \mathrm{~N}$ $\mathrm{ha}^{-1}$ followed by (36.80) at $100 \mathrm{~kg} \mathrm{ha}^{-1}$ and (34.50) at $70 \mathrm{~kg} \mathrm{ha}^{-1}$ respectively, while minimum days to flowering (30.57) was recorded in control treatment. Means value of days to flowering for cultivars showed that maximum days to flowering (38.25) was recorded in cultivar Purple Long, followed by (35.10) in Shamli cultivar, while minimum(32.60) was recorded in cultivar Black Long (Table 1).

Flowering is the character which is most responsive to the application of nitrogen. Different growth stages i.e. vegetative growth, reproductive growth and even fruit formation needs nitrogen optimum amount. Small concentration of nitrogen in any plant will lower the vigor and cause early flowering [16]. Similarly, by increasing fertilizer levels delayed in flowering was observed in prior experiments [17].

\section{Days to fruiting}

The statistical analysis of the data showed that days to fruiting were significantly affected for different cultivars and nitrogen levels, while their association was found non-significant. Means value of days to fruiting for nitrogen levels showed that maximum days to fruiting (64.55) was recorded in plants supplied with $130 \mathrm{~kg} \mathrm{~N}$ $\mathrm{ha}^{-1}$, followed by (53.00) at $100 \mathrm{~kg} \mathrm{ha}^{-1}$ and (50.44) at $70 \mathrm{~kg} \mathrm{ha}^{-1}$ respectively, while minimum days to fruiting (40.66) was recorded in control treatment. Means value of days to fruiting for cultivars showed that maximum days to fruiting (53.91) was recorded in cultivar Purple Long, followed by (52.83) in Shamli cultivar, while minimum(50.00) was recorded in cultivar Black Long (Table 1).

Same results were obtained by Sat and Saimbhi [18] who reported that increase doze of nitrogen results in more days for the fruit setting of eggplant. Cultivar Purple long could be utilizes the resources efficiently and gave earliest fruit set as compared to local Situation. Organic components enhanced the biological activities of microorganism that enhanced the reproductive responses of the plants. As a result the flowers initiation takes less time. Soil organic matters also ensure the availability of sufficient amount of phosphorus and nitrogen and ultimately increased photosynthetic activities. Consequently flowers appear more quickly as compared to control plots [19].

\section{Number of fruits plant ${ }^{-1}$}

Mean values and their statistical analysis showed that, both the factors (cultivar and nitrogen levels) had significant effect on the number of fruits palnt ${ }^{-1}$ of Brinjal, while interaction between them found nonsignificant. Nitrogen levels significantly affected number of fruits plant ${ }^{-1}$ of Brinjal, their mean values showed that more number of fruits plant ${ }^{-1}$ (16.37) was noticed in plants that were treated with $130 \mathrm{~kg} \mathrm{~N} \mathrm{ha}{ }^{-1}$, followed by (12.85) at $100 \mathrm{~kg} \mathrm{ha}^{-1}$ and (11.88) at $70 \mathrm{~kg} \mathrm{ha}^{-1}$ respectively, while fewer number of fruits plant ${ }^{-1}$ (9.03) was observed in control beds. Regarding cultivars, mean values showed that high number of fruits plant $^{-1}(15.37)$ was noted in 
Purple Long, followed by (12.75) in Shamli cultivar, while minimum (9.47) was recorded in cultivar Black Long (Table 1). More number of fruits plant ${ }^{-1}$ is related with the vegetative growth of plant. When the plants have increased number of leaves (food factory) this will result in vigorous growth of plants. Hence nitrogen is responsible for the vigorous growth of plants (vegetative) and resulted in more number of leaves, which gives more number of fruits plant $^{-1}$ ultimately [2]. Similar findings were noticed by Bobadi and Damme [20], who reported that increasing nitrogen application gave best result and significantly produced more number of fruits plant ${ }^{-1}$. Similar results were noticed by Nazeer et al. and Mishriky and Alphonse [21, 22], who reported that number of fruits plant ${ }^{-1}$ were increased with increasing nitrogen application.

\section{Fruit weight (g)}

Fruit weight was significantly affected by different cultivars and nitrogen levels, while their interaction was remained nonsignificant. Means value of fruit weight for nitrogen levels showed that maximum fruit weight $(74.50 \mathrm{~g})$ was recorded in plants supplied with $130 \mathrm{~kg} \mathrm{~N}$ ha, ${ }^{-1}$ followed by $(70.30 \mathrm{~g})$ at $100 \mathrm{~kg} \mathrm{ha}^{-1}$ and $(66.80 \mathrm{~g})$ at $70 \mathrm{~kg}$ $\mathrm{ha}^{-1}$ respectively, while minimum fruit weight $(62.27 \mathrm{~g})$ was recorded in control treatment. Means value of fruit weight for cultivars showed that maximum fruit weight (72.42g) was recorded in cultivar Purple Long, followed by (69.65g) in Shamli cultivar, while minimum (63.32g) was recorded in cultivar Black Long (Table 1).

Nitrogen significantly increased average fruit weight. Some of the prior studies about nitrogen application and their positive effect on the growth of plants noticed by Gupta et al. [3], who stated that increased rate of nitrogen resulted in high fruit weight. Akanbi et al. [14] also reported that nitrogen also increased the average fruit weight.

\section{Total yield ( ha $\left.^{-1}\right)$}

Mean values from the analysis of variance table reveals that total yield $\left(\mathrm{t} \mathrm{ha}^{-1}\right)$ were significantly affected for different cultivars and nitrogen levels, while their association was found non-significant. Means value of total yield $\left(\mathrm{t} \mathrm{ha}^{-1}\right)$ for nitrogen levels show that maximum total yield $\left(13.72 \mathrm{t} \mathrm{ha}^{-1}\right)$ was noticed in plants supplied with $130 \mathrm{~kg} \mathrm{~N} \mathrm{ha,-}$ ${ }^{1}$ statistically at par with $\left(11.90 \mathrm{t} \mathrm{ha}^{-1}\right)$ at 100 $\mathrm{kg} \mathrm{ha} \mathrm{h}^{-1}$ and $\left(10.55 \mathrm{t} \mathrm{ha}^{-1}\right)$ at $70 \mathrm{~kg} \mathrm{ha}^{-1}$ respectively, while minimum total yield (8.75 $\left.\mathrm{t} \mathrm{ha} \mathrm{ha}^{-1}\right)$ was recorded in control treatment. Means value of total yield for cultivars showed that maximum total yield (13.26 $\mathrm{t} \mathrm{ha}^{-1}$ ) was observed in cultivar Purple Long, followed by (11.08 $\left.\mathrm{t} \mathrm{ha}^{-1}\right)$ in Shamli cultivar, while minimum $\left(8.64\right.$ tha $\left.^{-1}\right)$ was recorded in cultivar Black Long (Table $1)$.

For the improvement of any crop the fruit production is very important and its advancement through various ways is needed. Highest production was observed with nitrogen at $130 \mathrm{~kg} \mathrm{ha}^{-1}$ even as small quantity was found in control treatment. Same results were obtained by Bobadi and Damme [20], who reported that increasing nitrogen levels gave best results and significantly produced the highest yield over control plants. Some prior experiments showed similar results as obtained by Jilani et al. [23], who found that high dose of nitrogen, resulted in increased yield. These results are also similar to Hossein et al. [24]. These findings were similar to Nazeer et al. and Mishriky and Alphonse [21, 22], who reported that application higher nitrogen rates had a good impact on yield.

\section{Survival percentage (\%)}

Survival percentage (\%) was significantly affected by different cultivars and nitrogen levels, while the interaction was recorded non-significant. Means value of survival percentage for nitrogen levels showed that maximum survival percentage $(98.50 \%)$ was 
recorded in plants supplied with $130 \mathrm{~kg} \mathrm{~N}$ $\mathrm{ha}^{-1}$ followed by $(94.20 \%)$ at $100 \mathrm{~kg} \mathrm{ha}^{-1}$ and $(86.11 \%)$ at $70 \mathrm{~kg} \mathrm{ha}^{-1}$ respectively, while minimum survival percentage (73.80\%) was recorded in control treatment. Means value of survival percentage for cultivars showed that maximum survival percentage $(95.38 \%)$ was recorded in cultivar Purple Long, followed by $(88.11 \%)$ in Shamli cultivar, while minimum $(81.15 \%)$ was recorded in Black Long (Table 1).

These results were same with the conclusion of [23], who obtained that increased nitrogen application produced significantly maximum survival percentage.

\section{Authors' contributions}

Conceived and designed the experiments: $\mathrm{G}$ Ayub, Performed the experiments: B Zainub, Analyzed the data: S Siddique \& B Zainub, Contributed reagents/ materials/ analysis tools: S Zeb, E Jamil , B Zainub \& $\mathrm{S}$ Siddique, Wrote the paper: $\mathrm{S}$ Siddique, $\mathrm{B}$ Zainub, S Zeb \& E Jamil.

\section{References}

1. Devi HJ, Maity TK, Paria NC \& Thapa U (2002). Response of brinjal (Solanum melongena L.) to different sources of nitrogen 29(1): 45-47.

2. Roychaudhury A, Chatterjee R \& Mitra SK (1995). Effect of different doses of nitrogen, phosphorous, potassium, calcium and iron on growth and development in Chilli. Dep't. Hort Kalyani West Bangal Indian 13(3): 9699.

3. Gupta A, Shukla V, Srinivas \& Rao JV (1978). Response of brinjal (Solanum melongena L.) to nitrogen, phosphorous and potassium fertilization with different plant spacing. Ind J Horti 35(4): 352-358.

4. Swarp V (1995). Genetic resources and breeding of Aubergine (Solanum melongena L.). Acta Horti 412: 71-79.

5. Farary A, Doganlar S \& Daunay MC (2007). Eggplant. In. C. Kole (ect)
Genome mapping and molecular breeding in plants 5(2):287-313.

6. Kalloo G (1993). Eggplant (Solanum melongena L.). In Kallo, G., B.O. (ed). Genetic improvement of vegetable crop 587-604.

7. Anonymous (2001). Food and Agriculture Organization, Production year book 54: 148-149.

8. Obho G, Ekperigin MM \& Kazeem MI (2005). Nutritional and hemolytic properties of eggplant leaves. $J F d$ compos Analy 18(1): 153-160.

9. Kiran J (2006). Effect of fertilizer, bio fertilizer and micronutrients on seed yield and quality of brinjal (Solanum melongena L). Department of seed science and Technumberlogy College of Agriculture, Dharwad India 1-2.

10. Wange SS \& Kale RH (2004). Effect of bio-fertilizer and nitrogen levels on brinjal crop. J Soil crop 14(1): 9-11.

11. Pervez MA, Ayub CM, Bashart A, Nave AV \& Nasir M (2004). Effect of nitrogen levels and spacing on growth and yield of radish (Raphanus sativus L.). Int J Agric Biol 6(3): 504-506.

12. Haque ME, Pual AK \& Sarker RJ (2011). Effect of nitrogen and boron on the growth and yield of tomato. Intern. J Bio-resource stresses manage 2(3): 277-282.

13. Oloniruha JA, Tenywa JS, Joubert GD, Marais D, Rubaihayo PR \& Nampala MP (2009). Effect of graded levels of nitrogen on growth and yield of egg plant in Kabba, Southern Guinea Savana ecological zone of Nigeria. 241242.

14. Akanbi WB, Togun AO, Olaniran OA, Akinfasoye JO \& Tairu FM (2007). Physico-chemical properties of eggplant (Solanum melongena L.) fruit in response to nitrogen fertilizer and fruit size. Agric J 2(1): 140-148. 
15. Roe EN \& Cornforth CG (2000). Effect of dairy lot scraping and composted dairy manure on growth, yield and profit potential of double-cropped vegetables. Compost Sci and Utilization 8(2): 320-327.

16. Zekri M \& Obreza A (2003). Plant nutrients for citrus tree, soil and water science Dept.Inst. Food and Agri. Sci. Uni. Florida.

17. Law-Ogbomo KE \& Egharevba RKA (2009). Effect of planting density and NPK fertilizer application on yield and yield components of tomato (Lycopersicum esculantum L.) in Forest location. World J Agri Sci5 (2):152-158.

18. Sat P \& Saimbhi MS (2003). Effect of varying levels of nitrogen and phosphorus on earliness and yield of brinjal hybrids. J Res Crops 4(2): 217222.

19. Shashidhara GB (2000). Integrated nutrient management for chilli (Capsicum annuum L.) in alfisols of Northern transition zone of Karnataka. M.Sc (Agri) Thesis, University of Agricultural Sciences, Dharward, India.

20. Bobadi S, \& Damme PV (2003). "Effect of nitrogen application on flowering and yield of eggplant (Solanum melongena L.)." Communications in agricultural and applied biological sciences 68(1): 5-13.

21. Nazeer A, Tanki MI \& Ahmed $N$ (1992). Response of chilli to N and P. Univ. Agri. Sci. Tech, Shalimar, Srinagar, Jammu and Kashmir, India. Haryana. J Hort Sci 20(1-2): 114-118.

22. Mishriky JF \& Alphonse M (1995). Effect of nitrogen and plant spacing on growth yield and fruit mineral composition of pepper (Capsicum annuuum L.). Dep't veg crop. Faculty of Agri Cario Uni Egypt 45(2): 413431.

23. Jilani MS, Afzal MF \& Waseem K (2008). Effect of different nitrogen levels on growth and yield of brinjal (Solanum melongena L.). J Agri Res 3(2): 44-46.

24. Hossein MA, Aroiee $H$, Fatemi $H$, Ameri A \& Karimpour S (2010). Response of eggplant (Solanum melongena L.) to different rates of nitrogen under field condition. Journal Central European Agriculture 11(4): 453-458. 